\title{
ČLÁNKY
}

\section{Kritická analýza judikatury Soudního dvora EU ve věcech určení mezinárodní příslušnosti soudů $v$ př́ípadě pomluvy a porušení osobnostních práv na internetu*}

\author{
Critical Analysis of the Case Law of the Court \\ of Justice EU in Regards to the International Jurisdiction \\ of Courts in Disputes Arising out of Defamation \\ and Infringements of Personality Rights on the Internet
}

Tereza Kyselovská**

\begin{abstract}
Abstrakt
Tento článek se vènuje analýze kritéria pro určeni př̌slušnosti soudi spočivajici v "mistě škoodné události“ pro spory vyplývajici z.pomluvy a porušeni osobnostnich práv informacemi zverejnènými na internetu, které je upraveno v článku 7 odst. 2 Nařżení Brusel Ibis. Predmètem analýsy jsou rozhodnutí Soudníbo dvora EU ve věcech Bier, Shevill, eDate a Bolagsupplysningen, ve kterých Soudni dvir EU mimo jiné vytvoril tzv. „mozaiku“ pro žaloby na nábradu škody a nové jurisdikéní kritérium „centrum zájmù poškozeného". Tato rozhodnuti jsou kriticky analyzována z.pobledu povaby šrené informaci na internetu a vhodnosti a úcelnosti této interpretace v kontextu cillu a principiu, na kterých je Nař̌zeni Brusel Ibis založenono.
\end{abstract}

Klíčová slova

Mezinárodni prǐslušnost; Nařzeni Brusel Ibis; mimosmluvni závąlkové vątaby; misto škodné události; centrum zájmů poškozenébo; mozaiková úprava; pomluva a porušení osobnostnich práv; internet; judikatura; Shevill; eDate; Bolagsupplysningen.

\section{Abstract}

This article deals with the analysis of the jurisdictional rule "place of the harmful event" for disputes arising out of defamation and infringements of personality rights by information published on the internet. This rule is governed by Article 7 Para 2 of the Brussels Ibis Regulation. The subject of the analysis are decisions of the Court of Justice of the EU, namely Bier, Shevill, eDate and Bolagsupplysningen, in which the Court, inter alia, created a so-called "mosaic" approach for damages and a new jurisdictional criterion ,center

\footnotetext{
* Tento článek vznikl v rámci projektu specifického výzkumu Masarykovy univerzity MUNI/A/1141/2017.

** JUDr. Tereza Kyselovská, Ph.D., odborná asistentka, Katedra mezinárodního a evropského práva, Právnická fakulta, Masarykova univerzita, Brno / Assistant professor, Department of International and European Law, Faculty of Law, Masaryk University, Brno, Czech Republic / E-mail: tereza.kyselovska@ law.muni.cz / ORCID: 0000-0002-3803-1350 / ResearcherID: J-2463-2016
} 
of interest". The aforementioned decisions are critically analyzed in terms of the nature of dissemination of information on the internet and the appropriateness and usefulness of this interpretation in the context of the objectives and principles underlying the Brussels Ibis Regulation.

\section{Keywords}

Jurisdiction; Brussels Ibis Regulation; Non-contractual Obligations; Place of the Harmful Event; Center of Interest; Mosaic Approach; Defamation and Infringement of Personality Rights; Internet; Case Law; Shevill; eDate; Bolagsupplysningen.

\section{1 Úvod}

\section{1 Úvodní poznámky}

Internet a moderní komunikační technologie změnili způsob sdílení informací. V „době tištěné“ bylo možné předvídat a do jisté míry omezit, kam se informace šírené prostřednictvím tištěných sdělovacích prostředků dostanou. Díky internetu se informace šiŕí relativně snadno, rychle a neomezenému okruhu př́ijemců. Tento vývoj s sebou přináší řadu právních otázek.

V obecné rovině je jednou z nich, jakým způsobem na onu „bezhraničnost“ a neomezenost internetu reaguje mezinárodní právo soukromé a procesní, které je tradičně založeno na principu teritoriality a ukotvení pravidel (kolizních norem, hraničních určovatelů a procesních norem) k území určitého státu. ${ }^{1}$ Konkrétní problematickou otázkou $\mathrm{v}$ tomto kontextu je určení mezinárodní př́islušnosti soudů $\mathrm{v}$ případech, kdy informace distribuovaná na internetu poškodila něčí pověst a způsobila mu tím škodu. V takovém př́padě se nabízí otázky: U soudů kterého státu se může poškozená osoba bránit žalobou, když je informace dostupná všude tam, kde je připojení k internetu? Jaké nároky, př́padně výši náhrady škody, může poškozená osoba u soudu uplatnit? Jakým způsobem se „rozdělí“ škoda mezi všechna potenciální sudiště?

Odpovědi na tyto otázky je nutné hledat $\mathrm{v}$ předpisech mezinárodního práva procesního (tento článek je zaměřen pouze na mezinárodní právo procesní Evropské unie).

1 Cílem tohoto článku není podrobný rozbor výzev a problémů, kterým mezinárodní právo soukromé a procesní na internetu čelí. Této problematice se autorka článku dlouhodobě věnuje ve svých publikacích, př́ikladmo KYSELOVSKÁ, Tereza. Působnost práva na internetu. In: POLČÁK, Radim a kol. Právo informačních technologií Praha: Wolters Kluwer, ČR, 2008, s. 29-64. ISBN 978-80-7598-046-5; KYSELOVSKÁ, Tereza. Elektronizace a její vliv na vybrané aspekty evropského mezinárodního práva soukromého. In: ROZEHNALOVÁ, Naděžda, Jiří VALDHANS, Klára DRLIČKOVÁ a Tereza KYSELOVSKÁ. Mezinárodni právo soukromé Evropské unie (Nařizeni Rím I, Nařzeni Ř́m II, Nařzeni Brusel I). Praha: Wolters Kluwer ČR, 2013, s. 411-439. ISBN 978-80-7478-016-5; KYSELOVSKÁ, Tereza. Vybrané otázky vlivu elektronizace na evropské mezinárodni právo soukromé a procesni: (se zamèrením na princip teritoriality a pravidla pro založeni mezinárodni prìslušnosti soudu ve sporech vyplývajicich ze smluvních závazkovyich vžtabui). Brno: Masarykova univerzita, Právnická fakulta, 2014, 228 s., Spisy Právnické fakulty Masarykovy univerzity, řada teoretická, Edice Scientia, sv. č. 487. ISBN 978-80-210-7424-8; ze zahraničních zdrojů relevantních ke zkoumané problematice např. SVANTESSON, Dan Jerker B. Solving the Jurisdiction Puzzle. Oxford: Oxford University Press, 2017, 246 s. ISBN 978-0-19-879567-4. 
Vzhledem k tomu, že př́slušné procesní předpisy vznikaly v době „před-internetové“, přichází ke slovu výklad podávaný Soudním dvorem Evropské unie (dále jen Soudní dvưr). Soudní dvưr měl již několikrát možnost vyjádřit se k aplikaci unijního (EU) mezinárodního práva soukromého a procesního na právní vztahy vznikající online. Tento článek se zabývá, jakou interpretaci Soudní dvưr vytvořil pro oblast vybraných mimosmluvních závazkových vztahů vznikajících na internetu.

\subsection{Cíle a struktura článku}

Cílem tohoto článku je kritická analýza a zamyšlení se nad interpretační činností Soudního dvora týkající se pravidel pro určení příslušného soudu ve sporech vyplývajících z pomluvy a porušení osobnostních práv na internetu. Článek je zaměřen poměrně úzce, nebot' se zabývá pouze vybranou judikaturou Soudního dvora k intepretaci článku 7 odst. 2 Nař́zení Brusel Ibis ${ }^{2}$ a v něm obsaženého kritéria „místo škodné události“. ${ }^{3}$ Zkoumaná rozhodnutí, na kterých bude ilustrován vývoj intepretace Soudního dvora uvedeného ustanovení, jsou rozsudky ve věci Bier, ${ }^{4}$ Shevill, ${ }^{5}$ eDate ${ }^{6}$ a Bolagsupplysningen. ${ }^{7}$

Na základě analýzy uvedených rozhodnutí Soudního dvora lze vymezit několik problémových otázek, které v souvislosti s výkladem jurisdikčního pravidla „místo škodné události“ vyvstávají: Je výklad podaný Soudním dvorem EU v souladu s principy a cíli Nařízení Brusel Ibis a jeho pravidel? Bere Soudní dvůr ve své interpretační činnosti do úvahy povahu a způsob šíření informací na internetu? Odpovídá teritoriální rozdělení škody a tzv. „mozaika“ zajištění právní jistoty a předvídatelnosti procesních stran? Dochází extenzívní interpretací $\mathrm{k}$ upřednostnění speciálních (alternativních) pravidel před pravidlem obecným?

$\mathrm{Na}$ základě uvedených problémových otázek sleduje tento článek ověření pracovní hypotézy: Mozaikový prǐstup dle článku 7 odst. 2 Narízeni Brusel Ibis je v rozporu se zachováním

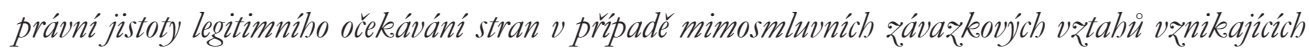
na internetu, a tím v rozporu s cilli a účelem Nařzeni Brusel Ibis.

2 Nařízení Evropského parlamentu a Rady (EU) č. 1215/2012 ze dne 12. prosince 2012 o př́ílušnosti a uznávání a výkonu soudních rozhodnutí v občanských a obchodních věcech (dále jen Nařízení Brusel Ibis).

3 Plné znění článku 7 odst. 2 Nařízení Brusel Ibis: „Osoba, keterá má bydliště v něketerém členském státě, mư̌̌e být v jiném členském státě ăalována ve vécech týkajicich se deliketni nebo kvazideliketni odpovédnosti u soudu mista, kede došlo nebo mữe dojit ke škodné události. "

4 Rozsudek Soudního dvora ze dne 30. listopadu 1976, Handelskwekerij G.J. Bier BV proti Mines de potasse d'Alsace SA., věc 21-76. In: Sbirka roz̧hodnutí. 1976, s. 1735.

5 Rozsudek Soudního dvora ze dne 7. března 1995, Fiona Shevill, Ixora Trading Inc., Chequepoint SARL a Chequepoint International Ltd proti Presse Alliance SA., věc C-68/93. In: Sbirka roz̧hodnutí. 1995, s. I-450. Podrobněji ke skutkovému stavu a předběžným otázkám srov. pozn. č. 18.

6 Rozsudek Soudního dvora (velkého senátu) ze dne 25. října 2011, eDate Advertising GmbH a dalsí proti X a Société MGN LIMITED, spojené věci C-509/09 a C-161/10. In: Sbirka roz̧hodnutí. 2011, I-10269. Podrobněji ke skutkovému stavu a předběžným otázkám srov. pozn. č. 25.

7 Rozsudek Soudního dvora (velkého senátu) ze dne 17. řijna 2017, Bolagsupplysningen OÜ a Ingrid Ilsjan proti Svensk Handel AB., věc C-194/16. In: Sbirka roz̧hodnutí. 2017. Podrobněji ke skutkovému stavu a předběžným otázkám srov. pozn. č. 67. 
Struktura článku sleduje uvedené problémové otázky a pracovní hypotézu. Článek je rozdělen do sedmi částí. Ve druhé části je stručně uvedena právní úprava př́slušnosti v Nařízení Brusel Ibis pro spory vyplývající z mimosmluvních závazkových vztahů. Třetí část se věnuje popisu a vysvětlení rozhodnutí ve věci Bier, Shevill a eDate. Na to navazuje část, která se věnuje kritice uvedených rozhodnutí a zejména tzv. „mozaice“, která byla právě pro tyto rozsudky Soudním dvorem využita. Pátá a šestá část se věnuje analýze a kritice nejnovějšího rozhodnutí ve věci Bolagsupplysningen, ve kterém měl Soudní dvůr možnost vypořádat se s nejkritizovanějšími důsledky své předchozí judikatury. V poslední, sedmé části je zhodnocena pracovní hypotéza a představeny závěrečné úvahy. Autorka článku doufá, že článek přispěje k odborné diskuzi v této oblast a naplní cíl být př́nosem pro právní vědu a praxi. Z pohledu právní vědy nabízí teoretickou analýzu rozhodnutí Soudního dvora a jeho přístup k výkladu speciálních (alternativních) pravidel př́slušnosti v Nařízení Brusel Ibis. Pro právní praxi přináší praktické tabulkové rozlišení jednotlivých rozhodnutí Soudního dvora, s přehledným vysvětlením a rozdělením možných sudišt' a uplatnitelných nároků.

\section{Mezinárodní př́slušnost soudů ve věcech mimosmluvních závazkových vztahů}

Pravidla pro určení mezinárodní př́islušnosti soudů pro spory vyplývající z mimosmluvních závazkových vztahů s přeshraničním prvkem (včetně pomluvy a porušení osobnostních práv) jsou upravena v článcích 4 a 7 odst. 2 Nařízení Brusel Ibis.

Článek 4 upravuje tzv. obecnou příslušnost, která je založena na bydlišti žalovaného. Nařízení Brusel Ibis obsahuje autonomní definici pojmu bydliště právnické osoby, ${ }^{8}$ bydliště fyzické osoby se určí podle lex fori. ${ }^{9}$ Nařízení z obecného pravidla bydliště žalovaného připouští několik výjimek. Jednou z nich je tzv. zvláštní (v české odborné literatuře někdy označovaná př́hodněji jako alternativní10 ${ }^{10}$ příslušnost upravená v článku 7.

Článek 7 odst. 2 Nař́zení Brusel Ibis ${ }^{11}$ upravuje mezinárodní příslušnost soudů ve věcech deliktní nebo kvazideliktní odpovědnosti. Podle tohoto ustanovení může být osoba,

8 Dle článku 63 Nařízení Brusel Ibis může bydlištěm právnické osoby být její sídlo, ústředí nebo hlavní provozovna.

9 Článek 62 Nařízení Brusel Ibis.

10 VADLHANS, Jiří. Nařízení Brusel I (alternativní př́islušnost). In: ROZEHNALOVÁ, Naděžda, Jiří VALDHANS, Klára DRLIČKOVÁ a Tereza KYSELOVSKÁ. Męinárodni právo soukromé Evropské unie (Nařzení Řim I, Nařzeni Řim II, Nařzeni Brusel I). Praha: Wolters Kluwer ČR, 2013, s. 224-265. ISBN 978-80-7478-016-5.

11 Tento článek je založen na analýze judikatury Soudního dvora EU, která se týká „,předchůdcư stávajícího Nařízení Brusel Ibis. Právní úprava v článku 7 odst. 2 Nařízení Brusel Ibis je stejná jako v článku 5 odst. 3 nařízení Rady (ES) č. 44/2001 ze dne 22. prosince 2000 o př́slušnosti a uznávání a výkonu soudních rozhodnutí v občanských a obchodních věcech (Nařízení Brusel I). Znění je stejné také jako v článku 5 odst. 3 Úmluvy ze dne 27. zárí 1968 o př́slušnosti a uznávání a výkonu rozhodnutí v občanských a obchodních věcech (Bruselská úmluva). 
která má bydliště v některém členském státě, žalována v jiném členském státě „,pred soudem mista, kede došlo nebo miṛ̌e dojit ke škodné události". Toto pravidlo je založeno na existenci zvláště úzké vazby mezi spory a soudy jiného členského státu, než jsou soudy určené podle bydliště žalovaného. Právní úprava je odůvodněna řádným výkonem spravedlnosti, účelnosti a hospodárnosti ř́zení ${ }^{12}$ a snadnosti provádění důkazů. ${ }^{13}$ Toto pravidlo, stejně jako všechny pojmy použité $\mathrm{v}$ nařízení, musí být vykládáno autonomně a s ohledem na systematiku a cíle nařízení. ${ }^{14}$ Vzhledem k tomu, že se jedná o výjimku z obecného pravidla, musí být interpretováno restriktivně s ohledem na účel a smysl speciálních (alternativních) pravidel př́slušnost. ${ }^{15}$

\section{Vývoj judikatury Soudního dvora}

Soudní dvưr se v několika rozhodnutích zabýval intepretací pojmu „místo, kde došlo nebo může dojít ke škodné události“ $v$ př́padech pomluvy a porušení osobnostních práv, a to jak v offline, tak online kontextu.

\subsection{Rozhodnutí ve věci Bier a Shevill}

Poprvé se Soudní dvưr intepretací kritéria „místo škodné události“ zabýval v roce 1976 v rozhodnutí ve věci Bier. Pojem „místo škodné události“ vyložil tak, že zahrnuje jak příčinu, tedy místo protiprávního jednání (forum delicti commissi), tak následek (přímý účinek), tedy místo, kde došlo ke vzniku škody (forum damni infecti). Je na žalobci, u soudů kterého místa podá žalobu. ${ }^{16}$ Má tak ,alternativu v rámci alternativy“.

Tato intepretace byla potvrzena a upřesněna v roce $1995 \mathrm{v}$ rozhodnutí ve věci Shevill. ${ }^{17}$ $\mathrm{V}$ tomto př́padě se jednalo o pomluvu publikovanou $\mathrm{v}$ tištěných novách, které byly

12 Preambule k Nařízení Brusel Ibis, odst. 16. Z vybrané judikatury srov. např. rozhodnutí ve věci Bier, odst. 11; rozhodnutí věci Shevill, odst. 19; rozhodnutí ve věci eDate, odst. 40; rozhodnutí ve věci Bolagsupplysningen, odst. 26.

13 Rozhodnutí ve věci Bolagsupplysningen, odst. 27.

14 Rozhodnutí ve věci Bolagsupplysningen, odst. 25; rozhodnutí ve věci eDate, odst. 38.

15 VADHANS, 2013, op. cit., s. 224.

16 VALDHANS, Jiří. Mimosmluvní závazky. In: ROZEHNALOVÁ, Naděžda, Klára DRLIČKOVÁ, Tereza KYSELOVSKÁ a Jiří VALDHANS. Úvod do mezinárodního práva soukromého. Praha: Wolters Kluwer, 2017, s. 189. ISBN 978-80-7552-699-1; MANKOWSKI, Peter. Art. 5. In: MAGNUS, Ulrich a Peter MANKOWSKI. Brussels I Regulation. European Commentaries on Private International Law. Sellier. European Law Publishers, 2007, s. 190. ISBN 978-3-935808-32-3.

17 Skutkorý stav pröpadu, puivodni rízeni a préedběžné otázky:

V tomto př́padě se jednalo o spor mezi žalobci paní Shevill (britská státní prríslušnice s bydlištěm v Anglii), Chequepoint SARL (společnost založená podle francouzského práva), Ixora Trading Inc. (společnost založená podle anglického práva) a žalovanou Presse Alliance SA (společnost založená podle francouzského práva). Presse Alliance publikovala v roce 1989 článek o drogovém zátahu, ve kterém byla jmenovitě zmíněna paní Shevill a žalující společnosti. Noviny byly publikovány ve Francii a distribuovány do dalších členských států, včetně Velké Británie. Paní Shevill považovala publikované informace za poškozující, nebot' naznačovaly její zapojení do nelegálního obchodu. V roce 1989 podali žalobci žalobu $\mathrm{k}$ anglickým soudům na náhradu škody za pomluvu. Žalovaná společnost napadla př́slušnost anglických soudů, nebot' noviny byly primárně prodávány ve Francii (237.000 výtisků), 15.500 výtisků bylo distribuováno do dalších zemí, z nichž pouze 230 bylo distribuováno do Anglie a Walesu. 
distribuovány do několika členských států EU. Soudní dvůr potvrdil, že žalobce může na základě článku 7 odst. 2 podat žalobu u soudů členského státu, kde došlo k protiprávnímu jednání, tedy zveřejnění poškozující informace. ${ }^{18}$ Toto místo se bude obvykle shodovat s bydlištěm žalovaného vydavatele, které se určí na základě článku $4 .{ }^{19}$ Soudy v tomto členském státě jsou př́slušné k rozhodnutí o celém rozsahu náhrady škody.

Žalobce může podat žalobu také u soudů v každém členském státě, kde byla dotčená publikace distribuována a kde poškozený tvrdí, že utrpěl újmu na své pověsti. ${ }^{20}$ Př́islušnost tohoto druhého okruhu soudů je omezena pouze k rozhodnutí o škodě, která byla způsobena na území př́slušného státu sudiště. ${ }^{21}$ Tento typ teritoriálně omezené soudní př́slušnosti se označuje jako tzv. „mozaika“ (Mosaiktheorie).

Shrneme-li výše uvedené, v př́padech údajného porušení osobnostních práv a pomluvy si žalobce (poškozená fyzická osoba) mohl na základě rozhodnutí ve věci Bier a Shevill, resp. kombinací obecného pravidla dle článku 4 a speciálního (alternativního) pravidla v článku 7 odst. 2, vybrat ze trrí možných sudišt'. U dvou sudišt' bylo možné žádat o náhradu celé újmy, u třetího sudiště byla náhrada škody omezena na újmu utrpěnou na území daného státu.

\begin{tabular}{|l|l|l|l|}
\hline \multicolumn{2}{|c|}{ Právní úprava } & Sudiště & Rozsah náhrady \\
\hline 1. & Článek 4 & Bydliště žalovaného & Náhrada celé škody \\
\hline 2. & Článek 7 odst. 2 & $\begin{array}{l}\text { Místo př́činného škodlivého jednání (misto } \\
\text { publikace, zpravidla v mistě bydlistě žalovaného) }\end{array}$ & Náhrada celé škody \\
\hline 3. & Článek 7 odst. 2 & $\begin{array}{l}\text { Místo škodlivého následku (místo distribuce, } \\
\text { kde poškozený utrpél újmu na pověsti) }\end{array}$ & $\begin{array}{l}\text { Teritoriálně omezená } \\
\text { náhrada ve výši újmy } \\
\text { způsobené na daném území }\end{array}$ \\
\hline
\end{tabular}

Soudní dvůr si byl vědom toho, jaké problémy může „,mozaika“ přinést; soudy v různých členských státech budou rozhodovat o různých aspektech jednoho sporu. Soudní dvůr

Britská Sněmovna lordů (House of Lords) předložila Soudnímu dvoru několik předběžných otázek, jejichž podstatou byla intepretace pojmu „místo škodné události“, resp. určení príslušnosti soudů v př́padě náhrady škody z titulu pomlouvačného článku publikovaného v novinách, a rozsahu náhrady škody, o které mohou príslušné soudy rozhodnout.

18 Pro interpretaci pojmu ,škodná událost“ je důležité, kde se nachází osoba, která poškozující informaci vytvořila a zveřejnila, nikoliv místo, kde byl obsah informace vytvořen. $Z$ tohoto důvodu nepovažoval Soudní dvůr za „místo škodné události“ místo, kde byly noviny vytišstěny, ale místo bydliště jejich vydavatele. Rozhodnutí ve věci Shevill, odst. 24.

19 Rozhodnutí ve věci Shevill, odst. 26.

20 Rozhodnutí ve věci Shevill, odst. 29.

21 Rozhodnutí ve věci Shevill, odst. 30 až 31; rozhodnutí ve věci Bolagsupplysningen, odst. 31; RAUSCHER, Thomas. Europäisches Zivilprozess- und Kollisionsrecht EuZPR/EUIPR. Kommentar. Band I. Brüssel Ia-VO. 4. vyd. Köln: Verlag Dr. Otto Schmidt, 2016, s. 343. ISBN 978-3-504-47202-3; Podle Mankowského přináší mozaikový prístup „velmi efeketivní rèéení jevu forum shopping v prĭpadé údajných obètí (poškoozených osob), a tím efektivně chrání legitimni jurisdikèní qájmy na stranè údajnébo pachatele. "In: MANKOWSKI, op. cit., s. 194. 
své rozhodnutí odůvodnil tím, že žalobce má vždy možnost podat žalobu na náhradu celé škody u soudů bydliště žalovaného dle článku 4 nebo u soudů místa protiprávního jednání, tedy zpravidla místa, kde má sídlo (bydliště) vydavatel informace (dle článku 7 odst. 2).22

\subsection{Rozhodnutí ve věci eDate}

Rozhodnutí ve věci Shevill se týkalo distribuce poškozujících informací v tištěných novinách. S rozvojem používání internetu se situace výrazně změnila. Slovy generálního advokáta Michala Bobka, ,jake ke tomu nevyhnutelné dochází v ére anonymního internetového hrdinství, všeobecně známého svým ublazeným stylem, porozumèním a umírnèností [...]"23 se pomluvy a jiné nepravdivé informace šíŕi mnohem rychleji, snadněji a efektivněji.

V roce 2011 se Soudní dvůr zabýval použitelností speciálního (alternativního) pravidla mezinárodní př́islušnosti v článku 7 odst. 2 na žaloby pro porušení osobnostních práv způsobené informacemi zveřejněnými na internetu. Jednalo se o rozhodnutí ve věci eDate. ${ }^{24}$ Bylo to první rozhodnutí týkající se vztahu pomluvy na internetu a unijního mezinárodního práva soukromého. Soudní dvůr dostal př́ležitost být „tviircem nových a inovátorem stávajicích" pravidel. ${ }^{25}$

22 Rozhodnutí ve věci Shevill, odst. 32.

23 Stanovisko generálního advokáta Michala Bobka přednesené dne 13. července 2017, Bolagsupplysningen OÜ a Ingrid Ilsjan proti Svensk Handel AB., věc C-194/16. In: Digitální Sbirka roz̧hodnutí. 2017, odst. 1.

24 Skutkový stav, piovodni ř́zeni a predběžné otázky: V tomto případě se jednalo o dvě spojené věci eDate (C-509/09) a Martinez (C-161/10). Pro zjednodušení je rozhodnutí v tomto textu označováno souhrnným názvem eDate.

Ve věci eDate šlo o spor mezi panem X (bydliště v Německu) a společností eDate Advertising GmbH (sídlo a místo podnikání v Rakousku). Rakouská společnost zveřejnila na svých webových stránkách informace o panu X, které považoval za hanobící a poškozující. Pan X vyzval rakouskou společnost, aby informace odstranila. Rakouská společnost tak učinila, nicméně pan X podal v roce 2007 žalobu u německých soudů svého bydliště žalobu. V žalobě se domáhal, aby soud zakázal rakouské společnost uveřejňovat jakékoliv informace o jeho osobě i pro futuro na území Německa. Rakouská společnost zpochybnila př́slušnost německých soudů.

Ve věci Martinez šlo o spor mezi panem Olivierem Martinezem a Robertem Martinezem (francouzští státní př́slušníci) a deníkem Sunday Mirror (sídlo ve Velké Británii). V roce 2008 uveřejnil britský deník ve svém internetovém vydání text a fotografie o panu Olivierovi Martinezovi (známém francouzském herci) a jeho otci. Pánové Martinezovi podali v roce 2008 žalobu k francouzskému soudu z titulu nerespektování soukromého života, ochranu soukromí a projevů osobní povahy. Anglický deník zpochybnil př́slušnost francouzských soudů.

Německý Bundesgerichtshof a francouzský Tribunal de Grande Instancia de Paris položili ve svých řízeních předběžné otázky k Soudnímu dvoru, který se je s ohledem na jejich objektivní souvislost rozhodl spojit.

Podstatou předběžných otázek bylo, zda: 1) je možné použít rozhodnutí ve věci Shevill i na pomluvu a porušení osobnostních práv na internetu 2) má být pojem „místo, kde došlo nebo může dojít ke škodné události“ a př́slušnost soudů založena na pouhé dostupnosti webových stránek z daného území? Pokud je nutná existence nějaké zvláštní souvislosti mezi webovými stránkami a státem sídla soudu, jaká kritéria je nutné vzít do úvahy?

25 ,In this case, the CJEU is indeed both an inventor and innovator. [...] the CJEU may be said to adhere to proactive innovation rather than reactive. "In: MAUNSBACH, Ulf. The CJEU as an Innovator - a New Perspective on the Development of Internet Related Case law. Masaryk. University Journal of Law and Technology [online]. 2017, roč. 11:1, s. 85 až 86 [cit. 12. 8. 2018]. Dostupné z: https://journals.muni.cz/mujlt/article/view/6669 
Soudní dvůr rozhodl, že interpretace pojmu „místo škodné události“ a závěry z rozhodnutí ve věci Shevill jsou použitelné i pro pomluvu na internetu. Žalobu na náhradu škody může poškozená fyzická osoba podat jak u soudů, kde došlo k protiprávnímu jednání (zveřejnění poškozující informace), tak u soudů místa, kde se škoda projevila. ${ }^{26} \mathrm{~V}$ př́ipadě internetu se ve druhém př́padě jedná o soudy všech členských států, na jejichž území je nebo byl př́stupný obsah informace. ${ }^{27}$ Př́íslušnost těchto soudů zůstává teritoriálně omezená pouze na škodu, která vznikla na tomto území. ${ }^{28}$ Jinými slovy, Soudní dvůr aplikoval „mozaiku“ na internet.

Soudní dvůr k těmto kritériím doplnil jedno další, kterým zohlednil závažnost újmy, celosvětovou působnost a dostupnost informací na internetu ${ }^{29}$ a ochranu základních lidských práv. ${ }^{30}$ Podle nového pravidla je možné žalobu podat u soudů místa, kde má žalobce (poškozená fyzická osoba) centrum zájmů (centre of interest, Mittelpunkt der Interessen). ${ }^{31}$ Tímto místem je obecně členský stát, ve kterém má žalobce své obvyklé bydliště. Mưže se jednat i o členský stát, u kterého lze prokázat obzvláště úzkou vazbu k poškozené osobě (př́kladem může být výkon pracovní činnosti v této zemi, společenské nebo rodinné vazby apod.). ${ }^{32}$ Soudy členského státu, ve kterém se nachází centrum zájmů poškozeného, mohou nejlépe posoudit dopad takových obsahů na práva dotčené osoby. ${ }^{33}$ Žalobce může u soudů místa centra svých zájmů podat žalobu na náhradu celé nemajetkové újmy, která mu údajně poškozujícími informacemi vznikla. ${ }^{34}$

Shrneme-li výše uvedené, v př́padech údajného porušení osobnostních práv a pomluvy na internetu si žalobce (poškozená fyzická osoba) může na základě kombinace rozhodnutí ve věci Shevill a eDate, resp. kombinací obecného pravidla dle článku 4 a speciálního

26 Rozhodnutí ve věci eDate, odst. 41; rozhodnutí ve věci Bolagsupplysningen, odst. 29.

27 Rozhodnutí ve věci eDate, odst. 51. Soudní dvůr v tomto ohledu dokonce zmírnil svou původní interpretaci. V rozhodnutí ve věci Shevill měly být informace aktivně distribuovány v tištěné podobě a reálně být dostupné na území př́slušného státu; v př́ípadě rozhodnutí eDate stačí, že informace je nebo byla dostupná (aktivně či pasivně).

28 Rozhodnutí ve věci eDate, odst. 51 a 52.

29 Rozhodnutí ve věci eDate, odst. 47. V prrípadě rozhodnutí ve věci eDate (spor týkající se pana Martineze) se jednalo o publikaci poškozujících informací ve sdělovacích prostředcích, nikoliv na „soukromém“ blogu. V dnešní době se stírá rozdíl mezi online a offline publikací. Sdělovací prostředky (noviny, časopisy) sice vychází stále v tištěné podobě, jejich existence se však čím dál více přesouvá na internet. Informace tak mohou být šířeny oběma dvěma způsoby.

30 Stanovisko generálního advokáta Cruz Villalóna přednesené dne 29. března 2011, eDate Advertising GmbH proti X (C-509/09) a Olivier Martinez a Robert Martinezproti MGN Limited (C-161/10), spojené věci C-509/09 a C-161/10. In: Sbirka rozhodnutí. 2011, I-10269, odst. 52; stanovisko generálního advokáta Bobka ve věci Bolagsupplysningen, odst. 36.

31 Podle Maunsbacha se Soudní dvůr při vytvoření kritéria „centrum zájmư inspiroval v zemích common law, jejichž právo využívá „,entre of interest theories“. In: MAUNSBACH, 2017, op. cit., s. 85.

32 Rozhodnutí ve věci $e$ Date, odst. 49.

33 Rozhodnutí ve věci eDate, odst. 48; rozhodnutí ve věci Bolagsupplysningen, odst. 34.

34 Rozhodnutí ve věci eDate, odst. 52; rozhodnutí ve věci Bolagsupplysningen, odst. 32. 
(alternativního) pravidla v článku 7 odst. 2 vybrat ze čtyř možných sudišt'. U tř́ sudišt' je možné žádat o náhradu celé újmy, u třetího sudiště je náhrada újmy omezena na újmu utrpěnou na území daného státu.

\begin{tabular}{|c|c|c|c|}
\hline & Právní úprava & Sudiště & Rozsah náhrady \\
\hline 1. & Článek 4 & Bydliště žalovaného & Náhrada celé škody \\
\hline 2. & Článek 7 odst. 2 & $\begin{array}{l}\text { Místo príícinného škodlivého jednání } \\
\text { (misto publikace, zpravidla v mistě bydlišté } \\
\text { žalovanébo) }\end{array}$ & Náhrada celé škody \\
\hline 3. & Článek 7 odst. 2 & $\begin{array}{l}\text { Místo škodlivého následku (všechna } \\
\text { mista, kde poškozujicí informace byla nebo } \\
\text { je dostupnâ) }\end{array}$ & $\begin{array}{l}\text { Teritoriálně omezená škoda } \\
\text { ve výši újmy způsobené } \\
\text { na daném území }\end{array}$ \\
\hline 4. & Článek 7 odst. 2 & Centrum zájmů poškozeného & Náhrada celé škody \\
\hline
\end{tabular}

Je otázkou, zda kritérium „,centrum zájmů poškozeného“ vytvořilo třetí samostatné jurisdikční pravidlo v rámci článku 7 odst. 2 Nařízení Brusel Ibis, ${ }^{35}$ nebo se jedná o „,podmnožinu“ kritéria místa škodlivého následku. ${ }^{36}$ Spíše k první možnosti, tedy novému samostatnému pravidlu, navádí podle některých autorů text rozhodnutí ve věci eDate. ${ }^{37}$ $\mathrm{V}$ takovém př́padě je nutné se ptát, jaký je právní základ pro vytvoření tohoto kritéria. ${ }^{38}$

\section{Kritika rozhodnutí Soudního dvora ve věci Shevill a eDate v kontextu internetu - cui bono?}

Hlavní kritika rozhodnutí Soudního dvora spočívá v automatickém použití mozaiky na pomluvu na internetu.

Při odůvodnění aplikace mozaikového přístupu se lze stále setkat s názorem, že osoba, která zveřejní informace na internetu, tak činí s vědomím, že informace mohou být dostupné kdekoliv. Z tohoto důvodu by jejich původce neměl být překvapen místy, kde informace může způsobit újmu, a tedy mnohostí potenciálních sudišt’ a práv rozhodných. ${ }^{39}$

35 Systematika článku 7 odst. 2 Nařízení Brusel Ibis: 1. příčinné škodlivé protiprávní jednání, 2. škodlivý následek, 3. centrum zájmů poškozeného.

36 Systematika článku 7 odst. 2 Nařizení Brusel Ibis: 1. příčinné škodlivé protiprávní jednání, 2.a) škodlivý následek, 2.b) centrum zájmů poškozeného.

37 Rozhodnutí ve věci eDate, odst. 51; MAUNSBACH, 2017, op. cit., s. 85; stanovisko generálního advokáta Bobka ve věci Bolagsupplysningen, odst. 74.

38 LUTZI, Tobias. Internet Cases in EU Private International Law - Developing a Coherent Approach. International and Comparative Law Quarterly [online]. 2017, roč. 66, s. 695 [cit. 18. 8. 2018]. Dostupné z: https://papers.ssrn.com/sol3/papers.cfm?abstract_id=2988596. Jedná se o ryze teoretickou otázku, která na praktické řešení případu nebude mít vliv. Nicméně i tak je zajímavá a důležitá, nebot' se týká prrístupu Soudního dvora k povaze speciálních (alternativních) pravidel.

39 K tomu srov. v odborné literatuře nejznámější a nejčastěji citované rozhodnutí australských soudů ve věci Dow Jones \& Company Inc. proti Gutnick, (2002) 210 CLR 575. In: SVANTESSON, 2017, op. cit., s. 97-98. 
Tento argument podle názoru autorky v dnešní době neobstojí. Mozaikový přístup v rozhodnutí ve věci Shevill byl vytvořen pro šíření informací v tištených médiích. Relativně snadná dostupnost informací jsou vlastnosti specifické pro internet, který v době vydání rozhodnutí ve věci Shevill v roce 1995 představoval spíše okrajový sdělovací prostředek. Internet změnil pravidla hry. Informace zveřejněné online jsou prŕístupné okamžitě, neomezenému počtu uživatelů. S vývojem strojových př́kladačů jsou informace dostupné v jazycích ovládaných širokou veřejností, mnohdy nezávisle na tom, zda původce informace zamýšlel zpř́ístupnit obsah i mimo dosah jeho kontroly. ${ }^{40}$ Padá i jazyková bariéra přenosu informací. Soudní dvůr v odůvodnění rozhodnutí ve věci eDate sám uvedl, že „internet snižuje užitečnost určovatele týkajici se šireni, jelikož rozsah šreni obsabu informaci na internetu je v zásadě univerzálni. Navíc z. technického blediska neni vždy možné tento rozsah šrreni s určitosti kvantifikovat ve vatahu ke konkéétnimu členskému státu, a proto ani ohodnotit újmu zpưsobenou výlučně v tomto členském státě" ${ }^{41}$ Rozdíl mezi online a offline šírením informací se stírá, uživatelé čerpají informace primárně právě z internetu. Mnoho vydavatelů a společností využívá služeb informační společnosti a platforem typu Facebook, Google apod. pro komunikaci a sdělování informací zákazníkům. ${ }^{42}$ Rostoucí počet služeb by bez internetu nemohl vůbec fungovat (např. Uber, AirBnB, Wikipedia a dalšî). Tyto služby nejsou nabízeny pouze podnikateli - profesionály. Proto skutečnost, že osoba užívá internet, neznamená, že se svým jednáním automaticky zaměřuje na celý svět. ${ }^{43}$

Na jedné straně, myšlenka územně omezené distribuce informací a s tím spojené územně omezené př́slušnosti soudů $\mathrm{k}$ rozhodnutí o náhradě škody je $\mathrm{v}$ souladu s principem teritoriality, který ovládá mezinárodní právo soukromé a procesní. Velmi zjednodušeně řečeno, na internetu neexistují zeměpisné hranice. Celá řada kritérií pro určení př́slušného soudu je však ukotvena k území určitého státu, což působí problémy pro aplikaci norem mezinárodního práva soukromého a procesního na vztahy vznikající na internetu.

Na straně druhé, „mozaika“v vontextu internetu znamená přiznání mezinárodní př́slušnosti soudům všech 28 (zatím) členských států EU. Informace zveřejněná na internetu

40 Rozhodnutí ve věci eDate, odst. 45.

41 Rozhodnutí ve věci eDate, odst. 46.

42 Stejně tak LUTZI, 2017, op. cit., s. 700. Př́istup k informacím lze do jisté míry omezit pomocí geoblokačních technologií. K tomu srov. SVANTESSON, 2017, op. cit., s. 201 a násl. Ale ani tyto technologie nejsou bez chyb a mohou vytvářet př́kážky volnému trhu v rámci EU. Z tohoto důvodu bylo přijato Nařizení (EU) 2018/302 Evropského parlamentu a Rady ze dne 28. února 2018 o řešení neoprávněného zeměpisného blokování a dalších forem diskriminace založených na státní příslušnosti, místě bydliště či místně usazení zákazníků v rámci vnitřního trhu a o změně nařízení (ES) č. 2006/2004 a (EU) 2017/2394 a směrnice 2009/22/ES.

43 Některé formy služeb je možné teritoriálně omezit, např. formou placeného předplatného (např. časopisy, noviny, e-knihy Kindle), registrace (např. přístup do odborných databázî), vyloučením dodání zboží do určité země (např. Amazon, eBay). Mnoho služeb je však založeno právě na volném přístupu a šíření k informacím (nap̌r. volně prrístupné encyklopedie typu Wikipedia, recenzní služby typu TripAdvisor a dalšî). Stejně tak LUTZI, 2017, op. cit., s. 701. 
je dostupná ve všech členských státech. I jen několik „návštěv“ na webové stránce, na které je údajně poškozující informace dostupná, by mohlo založit př́íslušnost soudů daného státu. ${ }^{44}$ Důležité samožrejmě je, aby žalobce měl v těchto státech určitou pověst, která byla danou informací poškozena.

Mozaikový přístup vytváří potenciálně mnohost sudišt'. V kontextu online vztahů je $\mathbf{v}$ rozporu s celou řadou principů ovládajících mezinárodní právo procesní a Nařízení Brusel Ibis. V tomto ohledu spočívá autorčina hlavní kritika „mozaiky“.

Mnohost možných sudišt' je v rozporu s principem právní jistoty a předvídatelnosti pravidel o soudní příslušnosti. ${ }^{45}$ Dává výhodu žalobci, který si může vybrat pro něj nejpř́znivější sudiště z potenciálně 28 možných míst. Jinými slovy, neúměrně podporuje forum shopping. ${ }^{46} \mathrm{~S}$ tím je spojeno riziko obtěžování. ${ }^{47}$ Žalovaný nemůže předvídat, ve kterém členském státě (členských státech) bude žalován. Teoreticky by mohl být žalován u soudů všech 28 členských států EU. V praxi jistě nebude časté, že by žalobce podal žaloby u více soudů různých členských států, nicméně to může být součástí procesní strategie žalobce nebo jím využito jako možná „hrozba“ potenciálních sudišt' vưči žalovanému.

Mnohost sudišt' s sebou nese potenciálně mnohost práv rozhodných, kterými se budou spory řídit. Kolizní normy pro určení práva rozhodného pro mimosmluvní závazkové vztahy jsou upraveny v Nařízení Rím II. ${ }^{48}$ Z působnosti nařízení jsou vyloučeny mimosmluvní závazkové vztahy, které vznikají z narušení soukromí a osobnostních práv, včetně pomluvy (článek 1 odst. 2 písm. g). Právo rozhodné se určí podle kolizních norem fora. ${ }^{49}$

$44 \mathrm{~K}$ této otázce se vyjádřil generální advokát Villalón ve stanovisku k věci e Date. Podle něj počet a původ „návštěv“ určité webové stránky může být ukazatelem určitého územního dopadu. Nicméně se jedná o ukazatele, který „nedává dostatečné qáruky pro presvédčivé a konečné stanoveni zpuisobené protiprávni škody“. In: Stanovisko generálního advokáta Villalóna ve věci eDate, odst. 50.

45 Preambule k Nařizení Brusel Ibis, odst. 15; stanovisko generálního advokáta Bobka ve věci Bolagsupplysningen, odst. 79.

$46 \mathrm{~S}$ pojmem forum shopping, tedy hledání pro žalobce nejpříznivějšího sudiště, bývají spojeny spíše negativní konotace. Takový přístup ale podle názoru autorky není vhodný. Nařízení Brusel Ibis jistou míru fora shopping sám umožňuje tím, že obsahuje nejen pravidlo obecné př́islušnosti, ale žalobce si může zvolit i alternativní sudiště dle speciálních pravidel, př́ípadně volby sudiště (článek 25). Mozaikový přístup $\mathrm{v}$ kontextu internetu ovšem dovádí forum shopping do stavu ad absurdum a je v rozporu s principy právní jistoty a předvídatelnosti, na kterých je Nařízení Brusel Ibis založeno.

47 Stanovisko generálního advokáta Bobka ve věci Bolagsupplysningen, odst. 88; stejně tak VANLEENHOVE, Cedric. The European Court of Justice in Bolagsupplysningen: The Brussels I Recast Regulation's jurisdictional rules for online infringement of personality righs further clarified. Computer Law \& Security Review [online]. 2018, č. 34, s. 643 [cit. 17. 8. 2018]. Dostupné z: https://biblio.ugent.be/publication/8561503

48 Nařízení Evropského parlamentu a Rady (ES) č. 864/2007 ze dne 11. července 2007 o právu rozhodném pro mimosmluvní závazkové vztahy.

49 V př́padě České republiky se jedná o \ 101 zákona č. 91/2012 Sb., o mezinárodním právu soukromém (ZMPS). 
Mozaikový př́stup je dále $\mathrm{v}$ rozporu s principem řádného výkonu spravedlnosti. Pouhá skutečnost, že je informace přímo dostupná ve všech členských státech, znamená pro původce informace (tradičně média a sdělovací prostředky) riziko, že by mohl být žalován v kterémkoliv členském státě. Toto riziko stoupá, pokud se bude jednat o veřejně známé osobnosti, celebrity, které jsou známé globálně (jako tomu bylo v př́ipadě herce Oliviera Martineze, jednoho z žalobců v rozhodnutí ve věci eDate). Jak zhodnotil generální advokát Villalón, „,nelže tedy rüci, že by takovéto re reseni napomáhalo žalobci nebo žalovanému v prédvídatelnosti prì uróováni pravidel ". 50

Podle některých názorů z rozhodnutí ve věci eDate vyplývá „zaujatost“ Soudního dvora směrem k ochraně zájmů poškozených osob. ${ }^{51}$ Zájmy žalobce (poškozeného) a žalovaného by měly být zohledněny stejným způsobem. Cílem speciálních (alternativních) pravidel příslušnosti není ochrana slabší smluvní strany, v tomto kontextu poškozené osoby. Jejich cílem je úzká vazba př́padu s konkrétním sudištěm. Je tomu tak i v případě 28 potenciálních sudišt'? Žalobce je tak chráněn více, nebot' si může vybrat z několika kritérií pro určení příslušného soudu. Mưže žalovat mimo jiné v centru svých zájmů, což ve většině případů bude v místě jeho bydliště, tedy u „domácího“ soudu. Mozaikový př́stup je tak v rozporu s principem actor sequitur forum rei (̌̌alobce žaluje u soudu žalovaného). ${ }^{52}$

Mozaikový př́stup je v rozporu s principem blízkosti sporu. Cílem článku 7 odst. 2 Nařízení Brusel Ibis je stanovit prríslušný soud, který bude blízký relevantním okolnostem sporu. Tato blízkost není zajištěna $\mathrm{v}$ případě škody, která vznikla zveřejněním informací na internetu. Taková škoda je nelokalizovatelná a v praxi je téměř nemožné určit, $\mathrm{k}$ jak velké škodě došlo v př́padě informací, které jsou „pouze“ dostupné na území př́slušného sudiště. Pokud by bylo možné škodu navázat k danému území, př́islušný soud by mohl rozhodnout pouze o ,zlomku v₹niklé škody, čmž by bylo soudu zabránèno $v$ celkovém nábledu na škodu, a to by mohlo ztížit celkové posouzeni kontextu véci, o keteré rozhoduje. Mirị tak výhoda, kterou nabizi blizkost soudu a skutkových okolností sporu, a tim i uřitečnost [čl. 7 odst. 2 nařŕzení č. 1215/2012]“.53 Př́islušný soud je omezen na projednání škody vzniklé na území př́slušného členského státu. Takové rozdělení škody je v př́ípadě informací publikovaných online v praxi velmi obtížné, ne-li nemožné. ${ }^{54}$

50 Stanovisko generálního advokáta Villalóna ve věci eDate, odst. 51.

51 VANLEENHOVE, 2018, op. cit., s. 646.

52 Systematika pravidel pro určení mezinárodní příslušnosti soudů v Nařízení Brusel Ibis je postavena na obecném pravidle (bydlišti žalovaného), ze kterého je celá řada výjimek. Jednou z nich je ochrana slabší smluví strany (spotřebitele, zaměstnance a pojistníka) v oddílech 3 až 5 . Tato pravidla mají přednost před obecnou př́slušností. Jejich cílem je ochrana slabší smluvní strany v kontraktačním procesu. K tomu srov. Preambuli k Nařízení Brusel Ibis, odst. 18.

53 Stanovisko generálního advokáta Villalóna přednesené dne 11. záři 2014, Pez Hejduk proti EnergieAgentur. NRW GmbH, věc C-441/13. In: Digitálni Sbirka roz̧hodnutí. 2014.

54 Stanovisko generálního advokáta Bobka ve věci Bolagsupplysningen, odst. 80. 
Mnohost sudišt' znamená fragmentaci žalob. Každý z př́islušných soudů je povolán $\mathrm{k}$ projednání žaloby $\mathrm{v}$ podstatě $\mathrm{v}$ té stejné věci. ${ }^{55}$ Je otázkou, jak by se řízení o částečných náhradách škody probíhající před soudy více členských států koordinovala. Nařízení Brusel Ibis je založeno na principu racionalizace řízení, k čemuž dopomáhá celá rada institutů, jako je litispendence (články 29 až 34) nebo spojení vzájemně závislých řízení (článek 8). ${ }^{56}$ Není jisté, nakolik by pravidla litispendence dokázala vyřešit řízení probíhající na základě jedné „úplné“ žaloby na celou náhradu škody (např. u soudů místa protiprávního jednánî) a několika „částečných“ územně omezených žalob u soudů míst, kde došlo ke vzniku škody. ${ }^{57}$

Další otázkou je účinek res iudicata spojený s rozsudkem vydaným o celé požadované náhradě škody napřr. soudem v místě centra zájmů poškozeného, a to vzhledem k možné navazující žalobě na náhradu škody u jednoho nebo několika částečně př́islušných soudư. ${ }^{58}$

Rozšíření „mozaiky“ na údajně poškozující informace na internetu neslouží legitimnímu zájmu žádného účastníka řízení a je v rozporu s cíli předvídatelnosti a řádného výkonu spravedlnosti. ${ }^{59}$ I když se zdá, že „mozaika“ upřednostňuje žalobce, slouží skutečně některému účastníkovi řízení? „Mozaika“v kontextu internetu je zbytečná. Pokud se žalobce může domáhat plné náhrady škody v centru svých zájmů, existuje nějaké odůvodnění, proč by se domáhal částečných náhrad škody ve více jiných členských státech? ${ }^{00}$ Podobně, byt' ne tak kriticky, lze nahlížet na kritérium centrum zájmů poškozeného. Soudní dvưr vytvořil v tomto kritériu další možné sudiště na výběr žalobci. Na jedné straně lze tento přístup chápat. Jedná se o poměrně rozumné a efektivní řešení do jisté míry neřešitelné pomluvy na internetu. Na straně druhé tím Soudní dvưr dále oslabil princip actor sequitur forum rei, nebot' umožnil žalobci zahájit řízení o náhradě celé

55 LUTZI, 2017, op. cit., s. 695.

56 Stanovisko generálního advokáta Bobka ve věci Bolagsupplysningen, odst. 81.

57 Pokud žalobce podá více žalob z titulu pomluvy na internetu u soudů více členských států na základě článku 7 odst. 2 a místa škodlivého následku, bude se jednat o žaloby mezi týmiž účastníky v téže věci a předmětem sporu bude náhrada újmy vzniklé na př́islušném území.

Vzájemně související řizení jsou upravena v článku 30 a násl. Nařízení Brusel Ibis. Jedná se o tak úzce spojené žaloby, že jejich projednání a rozhodnutí o nich ve společném řízení je vhodné $\mathrm{k}$ tomu, aby se zabránilo vydání vzájemně neslučitelných rozhodnutí v oddělených řízeních (článek 30 odst. 3). Pokud jsou u soudů různých členských států zahájena navzájem související řízení, může soud, u kterého bylo řízení zahájeno později, řízení přerušit (článek 30 odst. 1). Soud může na návrh strany řízení prohlásit, že není příslušný, dokud není řízení u soud, u kterého bylo řízení zahájeno jako první, skončeno v prvním stupni a pokud tento první soud je pro tato řízení příslušný a spojení těchto řízení je podle jeho práva př́pustné (článek 30 odst. 2). K tomu srov. také Preambuli k Nařízení Brusel Ibis, odst. 21; LUTZI, 2017, op. cit., s. 695.

58 Stanovisko generálního advokáta Bobka ve věci Bolagsupplysningen, odst. 82.

59 Stanovisko generálního advokáta Bobka ve věci Bolagsupplysningen, odst. 90.

60 Stanovisko generálního advokáta Bobka ve věci Bolagsupplysningen, odst. 88. 
škody v „domácím“ sudišti, typicky místě svého bydliště. Fakticky se tím přiklonil k foru actoris. $^{61}$

Soudní dvůr odůvodnil „centrum zájmư tím, že je v souladu s cílem předvídatelnosti pravidel pro určení příslušnosti ve vztahu k žalobci i žalovanému. Žalobci pomůže určit, kde může podat žalobu. Žalovaný může předvídat, kde by mohl být žalován, nebot' jako vydavatel informace mohl $\mathrm{v}$ době zveřejnění znát centrum zájmů osoby, které se informace týkala. ${ }^{62} Z$ rozhodnutí Soudního dvora ve věci eDate vyplývá, že poškozená osoba může mít pouze jedno centrum zájmů. ${ }^{63}$ Toto tvrzení podle názoru autorky také není přesné. Lze si představit situaci, kdy osoba (např. veřejně známá osobnost nebo nadnárodní korporace) bude mít center zájmů více ve více státech.

Je zřejmé, že zachování „mozaiky“ pro žaloby na náhradu škody je v rozporu s principy, na kterých je Nařízení Brusel Ibis založeno. Je také v rozporu s požadavkem restriktivní interpretace speciálních (alternativních) pravidel. Podle názoru autorky se Soudní dvůr snaží „za každou cenu“ přizpůsobit stávající pravidla pro právní vztahy vznikající na internetu. Jak je vidět na kritice rozhodnutí ve věci eDate a Bolagsupplysningen, ne vždy se jedná o št’astné řešení. Soudní dvưr se mohl inspirovat ve své starší judikatuře, ze které vyplývá, že pokud je míst určených na základě speciální (alternativnî) príislušnosti př́liš mnoho nebo by bylo velmi obtížené je zjistit, tato pravidla nelze z důvodu zachování právní jistoty a předvídatelnosti použít a je nutný návrat do obecného pravidla bydliště žalovaného. ${ }^{64}$ Soudní dvůr mohl tuto argumentaci použít jako důvod pro vyloučení „mozaiky“ v př́ípadě vzniku „nelokalizované škody“ ve sporech o náhradu škody dle článku 7 odst. 2 a pomluvy na internetu. Žalobci by zůstala možnost podat žalobu nejen

61 Stanovisko generálního advokáta Villalóna ve věci Hejduk, odst. 26. Nařízení Brusel Ibis, s výjimkou speciální (alternativnî) př́íslušnosti, neupřednostňuje bydliště žalobce. Stejně tak LUTZI, 2017, op. cit., s. 696.

62 Rozhodnutí ve věci eDate, odst. 50.

$63 \mathrm{~V}$ rozhodnutí Soudního dvora ve věci eDate je používána formulace „centrum zájmů poškozeného“, nikoliv „,centra zájmů poškozeného“. Opačný názor uvedl generální advokát Bobek ve stanovisku ve věci Bolagsupplysningen, odst. 116, podle kterého může mít fyzická (i právnická) osoba více center zájmů. Pokud bychom prijjali tuto intepretaci, znamenalo by to další tř́ištění př́slušností a v konečném důsledku sníženî právní jistoty a předvídatelnosti pro účastníky právních vztahů.

64 Př́kladmo rozhodnutí Soudního dvora ze dne 19. února 2002, Besix SA proti Wasserreinigungsbau Alfred Kretzschmar GmbH \& Co. KG (WABAG) a Planungs- und Forschungsgesellschaft Dipl. Ing. W. Kretzschmar GmbH \& KG (Plafog), věc C-256/00. In: Sbirka roz̧bodnutí. 2002, I-01699. Rozhodnutí se týkalo interpretace článku 7 odst. 1 písm. a) Nařízení Brusel Ibis (př́slušnost ve sporech ze smluv), nicméně jeho závěry lze použít i pro článek 7 odst. 2 Nařízení Brusel Ibis. Spornou otázkou bylo určení „místa plněnî závazku“ v př́padě existence výlučné konkurenční doložky, kdy povinnosti z ní vyplývající měly být plněny celosvětově. Soudní dvưr rozhodl, že speciální (alternativnî) pravidlo př́slušnosti se nemůže v takovém případě aplikovat. „Misto plnění závazku nemǐž být jednoznačně určeno, nebot' spočivá v povinnosti nèco nedèlat, jež neni omeẓena žádnými geografickými branicemi. Z tohoto divodu mữ̌e být takových mist plnèni neomez̧eně mnoho. Príslušnost soudu musi být určena na zákeladě obecnébo pravidla v [článku 4 Narízeni Brusel Ibis]. "Odst. 55 rozhodnutí. 
v místě centra svých zájmů, ale i v místě bydliště žalovaného nebo v místě příčinného protiprávního jednání (ve většině případů povedou obě dvě místa ke stejnému sudišti). ${ }^{65}$ Důsledkem intepretace Soudního dvora je upřednostňování speciálního pravidla dle článku 7 odst. 2 na úkor obecného dle článku 4. Přitom by s ohledem na systematiku nař́izení mělo platit, že v pochybnostech je vždy nutný návrat k bydlišti žalovaného dle článku $4 .{ }^{66}$

\section{Rozhodnutí ve věci Bolagsupplysningen}

Soudní dvưr v rozhodnutích ve věci Shevill a eDate vytvořil poměrně velkorysá pravidla týkající se mezinárodní příslušnosti soudů s ohledem na pomluvu šírenou pomocí tištěných sdělovacích prostředků a posléze rozšířené na újmu způsobenou na pověsti fyzické osoby informacemi zveřejněnými na internetu. V roce 2017 přidal Soudní dvůr další stř́ípek k intepretaci kritéria „místo škodné události“ v rozhodnutí ve věci Bolagsupplysningen. ${ }^{67}$

65 Podobně argumentoval generální advokát Villalón ve stanovisku ve věci Hejduk v odst. 45. Tento př́pad se sice týkal porušení autorského práva na internetu, nicméně závěry jsou použitelné i pro pomluvu a porušení osobnostních práv na internetu. Stejně tak Lutzi: „Instead of bending and twisting the interpretation of these provisions until they can be applied to internet cases, the approach [...] would allow the courts to disregard these provisions altohether where their application would lead to results that cannot be justified by the considerations that underline them. Instead, one would naturally fall back to criteria that do not raise these difficulties - the place of acting in Article 7 (2), the place of establishment in Article 7 (5), or the domicile of the defendant." In: LUTZI, 2017, op. cit., s. 711.

66 Podobné úvahy lze nalézt i v PASTORKOVÁ, Mária. Alternativní příslušnost - alternativa či východisko? In: KYSELOVSKÁ, Tereza, ROZEHNALOVÁ, Naděžda a kol. Rozhodování Soudního dvora EU ve vécech přslušnosti (analýza roz̧odnuti dle Nařzeni Brusel Ibis). Brno: Masarykova univerzita, řada teoretická, Edice Scientia, sv. č. 507, 2014, s. 135-175. ISBN 978-80-210-7770-6.

67 Skutkorý stav přpadu, puivodní ř́zeni a prédběžné otázky: Společnost Bolagsupplysningen OÜ je estonská společnost (sídlo v Tallinu, Estonsku), která provozuje svou obchodní činnost převážně ve Švédsku. V roce 2015 byla na webových stránkách švédského svazu obchodu Svensk Handel AB zařazena na černou listinu z důvodu údajných podvodů a nekalých obchodních praktik. Na diskuzním fóru těchto webových stránek se posléze objevily nenávistné komentáře čtenářu a výhrưžky proti estonské společnosti a jejím zaměstnancům.

Estonská společnost podala spolu se svou zaměstnankyní paní Ilsjan v záŕi 2015 žalobu u estonských soudů proti švédskému svazu. Tvrdila, že zveřejněné informace jsou nepravdivé, negativně se dotkly její cti, pověsti a dobrého jména a poškodily její podnikání ve Švédsku. Žalující společnost tvrdila, že estonské soudy jsou prríslušné k rozhodnutí ve věci, nebot' středisko jejích zájmů se nachází v Estonsku (je zde její obchodní vedení, účetnictví, personální útvar a dalšî). Podle jejího tvrzení se účinky protiprávního jednání švédského svazu projevily právě v Estonsku.

Společnost Bolagsupplysningen OÜ se u estonských soudů domáhala, aby nařídily švédskému svazu opravu informací a odstranění komentářu z webových stránek. Sekundárně se domáhala náhrady škody, která jí v důsledku zveřejněných informací a komentářů vznikla.

Prvostupňový i odvolací estonský soud žalobu zamítl z důvodu nedostatku mezinárodní příslušnosti estonských soudů. Nejvyšší soud Estonska (Riigikohus) oddělil žalobu společnosti Bolagsupplysningen OÜ od paní Ilsjan (v jejím prrípadě byla věc vrácena soudu prvního stupně k novému rozhodnutí o prííslušnosti). Nicméně ohledně př́ílušnosti estonských soudů ve věci žalovy společnosti Bolagsupplysningen OÜ měl pochybnosti, a proto položil Soudnímu dvoru EU tři prédběžné otázky. Jejich podstatou bylo: 1) Pokud by byla př́slušnost estonských soudů omezena pouze na škodu, která společnosti Bolagsupplysningen OÜ vznikla v Estonsku, mohou estonské soudy nařídit švédskému svazu, aby opravil a odstranil údajně závadné informace?

2) Mưže právnická osoba, které údajně vznikla újma, uplatnit nároky na opravu údajů, uložení povinnosti odstranit komentáře a náhradu škody v celé výši u soudů místa, ve kterém se nachází centrum jejích zájmů (podle tvrzení estonské společnosti v Estonsku)?

3) Jakým způsobem se určí „centrum zájmư “ právnické osoby, resp. lze za toto místo považovat např. její sídlo? 
Tento prrípad se od předcházejících odlišuje ve dvou hlavních skutečnostech: (1) Právnická osoba (nikoliv fyzická osoba) se primárně domáhala opravy údajně nepravdivých informací a odstranění negativních komentářů zveřejněných na internetu a (2) pouze podpůrně náhrady újmy, která byla těmito údaji údajně způsobena na její pověsti. ${ }^{68}$

Shrneme-li položené předběžné otázky, Soudní dvưr se musel vypořádat s několika okruhy problému: (a) Jsou pravidla speciální (alternativnî) př́íslušnosti pro žaloby z titulu pomluvy a porušení osobnostních práv upravená v článku 7 odst. 2 Nařízení Brusel Ibis použitelná nejen pro fyzické, ale i právnické osoby? Mají i právnické osoby osobnostní práva hodná právní ochrany? (b) Je možné použít kritérium „,centrum zájmů poškozeného“ i v př́padě právnické, nejen fyzické, osoby? Pokud ano, jakým zpơsobem se určí „,centrum zájmů poškozeného"v př́padě právnické osoby? (c) Jak se posoudí vzájemný vztah tzv. mozaiky vytvořené rozhodnutím ve věci Shevill, kdy je národní soud př́slušný k rozhodnutí pouze o části náhrady škody, která vznikla na jeho území, s požadavkem na opravu a odstranění údajně poškozujících údajů z webových stránek, který je v podstatě nedělitelný?

a) Jeden ze zásadních bodů rozhodnutí Soudního dvora je, že pro aplikaci speciálního (alternativního) pravidla upraveného v článku 7 odst. 2 Nař́zení Brusel Ibis není rozhodující, zda má utrpěná újma majetkovou nebo nemajetkovou povahu. ${ }^{69}$ Pro aplikaci kritérií pro určení mezinárodní př́slušnosti soudů ve věcech mimosmluvní odpovědnosti za škodu způsobenou na pověsti není nutné rozlišovat mezi fyzickými i právnickými osobami. Tento závěr vychází ze stanoviska generálního advokáta Bobka, který se velmi podrobně věnoval existenci a obsahu osobnostních práv právnických osob. ${ }^{70}$

b) Kritérium „centrum zájmư“ je možné použít jak pro fyzické, tak právnické osoby. Pro určení „,centra zájmư “ právnické osoby není relevantní, zda se jedná o majetkovou nebo nemajetkovou újmu. ${ }^{71} \mathrm{~S}$ ohledem na určení místa „centra zájmů“ poškozeného se u fyzické osoby zpravidla jedná o místo jejího bydliště, pokud jiné indície nemohou prokázat zvláště úzkou vazbu k území jiného členského státu. ${ }^{72} \mathrm{U}$ právnické osoby by se mělo jednat o místo, ve kterém vykonává svou hlavní podnikatelskou činnost. Byt' se centrum zájmů právnické osoby může v mnoha př́ípadech

$68 \mathrm{~V}$ př́padě rozhodnutí ve věcech Shevill a eDate se jednalo o žaloby fyzických osob, které se primárně domáhaly náhrady škody a sekundárně odstranění údajně poškozujících informací.

69 Rozhodnutí ve věci Bolagsupplysningen, odst. 36.

70 Generální advokát Bobek na základě analýzy judikatury soudů členských států, Evropského soudu pro lidská práva a Soudního dvora EU dovodil, že i právnické osoby mají celou řadu základních práv, včetně osobnostních. Některé členské státy výslovně zákonně upravují např. dobrou pověst nebo dobré jméno právnických osob. Článek 7 odst. 2 Nařízení Brusel Ibis je tak podle Bobka „víceúrovňovým ustanovenim v tom smyslu, že pravidla o soudni prǐslušnosti v něm obsažená se použiji bez obledu na presný vnitrostátni právní základ pro žalobu, at’ u乏̌jde o bmotnèprávni ochranu osobnostnich práv priznanou na základè ústavně chránèného zákeladníbo práva, nebo o ochranu založenou na základè zákona ci judikatury, nebo o kombinaci obou zpiosobù ochrany ". In: Stanovisko generálního advokáta Bobka ve věci Bolagsupplysningen, odst. 58.

71 Rozhodnutí ve věci Bolagsupplysningen, odst. 37.

72 Rozhodnutí ve věci Bolagsupplysningen, odst. 40; rozhodnutí ve věci eDate, odst. 49. 
shodovat se sídlem právnické osoby, nemusí být sídlo samo o sobě rozhodujícím kritériem $^{73}$ (na rozdíl od fyzických osob je běžné, že si právnická osoba založí sídlo bez jakékoliv vazby na dané územî). Do úvahy je nutné ad hoc vzít všechny rozhodné skutečnosti. ${ }^{74}$ Může se jednat o obrat, počty zákazníků, jiné profesionální kontakty apod. Pokud by tedy poškození pověsti bylo právnickou osobou pocit'ováno silněji v jiném členském státě, než jejího sídla, byla by založena příslušnost těchto jiných soudů. ${ }^{75}$ Pokud by nebylo možné určit centrum zájmů právnické osoby, nebot' převážná část podnikatelské činnosti není v daném státě vykonávána, žalobce nemůže podat žalobu u soudů místa, kde se škoda projevila. ${ }^{76}$

Možnost podat žalobu u soudů v místě „,centra zájmů poškozeného“ není vedeno zájmem na ochraně žalobce, ale zájmem na řádném výkonu spravedlnosti. ${ }^{77}$ Soudy tohoto státu mohou lépe rozhodovat o sporu. ${ }^{78}$ Cílem speciální (alternativnî) př́íslušnosti také není ochrana slabší smluvní strany, jako je tomu v prŕípadě prríslušnosti u spotrebitelských nebo individuálně pracovních sporů. ${ }^{79}$

Soudy členského státu, ve kterém se nachází centrum zájmů poškozené právnické osoby, jsou příslušné $\mathrm{k}$ rozhodnutí o opravě údajů a odstranění komentářů z webových stránek a náhradě celé škody u soudů členského státu. ${ }^{80}$

c) Soudní dvưr zachoval (do jisté míry) „mozaiku“ vytvořenou rozhodnutím Shevill a potvrzenou rozhodnutím eDate. ${ }^{81}$ Poškozená osoba může podat žalobu u soudů všech členských států, na jejichž území je nebo byly poškozující informace př́ístupné na internetu, a kde byla tímto její pověst poškozena. Tyto soudy jsou př́slušné k rozhodnutí pouze o újmě způsobené na území př́slušného členského státu. ${ }^{82}$

73 Rozhodnutí ve věci Bolagsupplysningen, odst. 41.

74 Podle generálního advokáta Bobka je nutné se zaměřit na faktickou a sociální situaci žalobce v kontextu povahy konkrétního dotčeného prohlášení. Stanovisko generálního advokáta Bobka ve věci Bolagsupplysningen, odst. 100 .

75 Stejně tak Stanovisko generálního advokáta Bobka ve věci Bolagsupplysningen, odst. 112.

76 Rozhodnutí ve věci Bolagsupplysningen, odst. 43.

77 Rozhodnutí ve věci Bolagsupplysningen, odst. 38.

78 Rozhodnutí ve věci Bolagsupplysningen, odst. 39.

79 Rozhodnutí ve věci Bolagsupplysningen, odst. 39; stejně tak Bobek ve stanovisku ve věci Bolagsupplysningen, odst. 61 až 69. V mnoha sporech týkajících se pomluvy a ochrany osobnosti vystupuje zpravidla poškozená fyzická osoba, která se brání proti publikaci v určitém periodiku vydávaném právnickou osobou. Nicméně fyzická osoba nemůže být v těchto sporech automaticky považována za slabší smluvní stranu, a tím v režimu příslušných ochranných ustanovení. Různé osoby mohou vystupovat jak na straně žalobce, tak na straně žalovaného. Internet demokratizoval šíření a sdílení informací. Již neplatí premisa, že žalobcem je „slabá“ fyzická osoba a žalovaným „silná“ právnická osoba.

80 Rozhodnutí ve věci Bolagsupplysningen, odst. 44.

81 V tomto ohledu se Soudní dvůr odchýlil od stanoviska generálního advokáta Bobka, který nepovažoval za účelné a vhodné zachovat mozaikovou úpravu a vyzval Soudní dvưr k přezkumu př́liš širokých pravidel týkajících se speciální (alternativní) př́slušnosti.

82 Rozhodnutí ve věci Bolagsupplysningen, odst. 47; rozhodnutí ve věci eDate, odst. 51 a 52. 
Soudní dvůr vzal do úvahy, že informace se mohou na internetu šírit relativně neomezeně. Návrh na opravu údajů a odstranění komentářu je jediný a nerozdělitelný. Z podstaty věci o něm může rozhodnout pouze jediný soud. A to, podle Soudního dvora, soud členského státu, který je př́slušný pro rozhodování o celém nároku ve věci náhrady škody. ${ }^{83}$ Jinými slovy, takový návrh je možné podat pouze u soudů určených podle místa bydliště žalovaného (dle článku 4), u soudů místa, kde došlo k prŕíčinnému protiprávnímu jednání (zveřejnění poškozující informace) nebo u soudů místa, kde se nachází centrum zájmů poškozeného (obě dvě kritéria dle článku 7 odst. 2).

Návrh na opravu údajů a odstranění komentárư nelze dle Soudního dvora podat u soudů každého členského státu, na jehož území jsou nebo byly př́istupné informace na internetu. ${ }^{84}$ Poškozená osoba ale může stále využít „mozaiku“ pro žalobu na náhradu škodu a podat žalobu u všech soudů členských států, na jejichž území byla její pověst poškozena. ${ }^{85}$

Shrneme-li výše uvedené, je zřejmé, že Soudní dvůr zachoval systematiku a intepretaci článku 7 odst. 2 z předcházejících rozhodnutí ve věci Shevill a eDate, a to včetně kritizované „mozaiky“. Soudní dvưr nicméně upřesnil, o jaké nároky lze žádat. V př́ipadech údajného porušení osobnostních práv a pomluvy na internetu si žalobce (poškozená fyzická nebo právnická osoba) může stále vybrat ze čtyř možných sudišt'. U tří sudišt' je možné žádat o náhradu celé újmy, a to včetně opravy či odstranění závadných informací na internetu. U čtvrtého sudiště je náhrada škody omezena na újmu utrpěnou na území daného státu a není zde možné žádat o opravu nebo odstranění závadných informací.

\begin{tabular}{|c|c|c|c|}
\hline & Právní úprava & Sudiště & Rozsah náhrady \\
\hline 1. & Článek 4 & Bydliště žalovaného & $\begin{array}{l}\text { Náhrada celé škody, včetně } \\
\text { opravy nebo odstranění } \\
\text { informací na internetu }\end{array}$ \\
\hline 2. & Článek 7 odst. 2 & $\begin{array}{l}\text { Místo př́íčinného škodlivého jednání (misto } \\
\text { publikeace, zpravidla v mistě bydlisté q̌alovanébo) }\end{array}$ & $\begin{array}{l}\text { Náhrada celé škody, včetně } \\
\text { opravy nebo odstranění } \\
\text { informací na internetu }\end{array}$ \\
\hline 3. & Článek 7 odst. 2 & $\begin{array}{l}\text { Místo škodlivého následku (v̌̌echna mista, } \\
\text { kede poškozujicí informace byla nebo je dostupnâ) }\end{array}$ & $\begin{array}{l}\text { Teritoriálně omezená škoda } \\
\text { ve výši újmy způsobené } \\
\text { na daném území }\end{array}$ \\
\hline 4. & Článek 7 odst. 2 & Centrum zájmů poškozeného & $\begin{array}{l}\text { Náhrada celé škody, včetně } \\
\text { opravy nebo odstranění } \\
\text { informací na internetu }\end{array}$ \\
\hline
\end{tabular}

83 Rozhodnutí ve věci Bolagsupplysningen, odst. 48.

84 Rozhodnutí ve věci Bolagsupplysningen, odst. 49.

85 Tento závěr vyplývá ze stanoviska generálního advokáta Bobka ve věci Bolagsupplysningen, odst. 84. Žaloby na náhradu škody lze (do jisté míry) kvantitativně přizpůsobit. Náprava v podobě opravy nebo odstranění informací je nedělitelná. 
Bude-li se rozhodnutí Soudního dvora aplikovat na spor v původním řízení, žalobce to jistě nepotěší. Společnost Bolagsupplysningen OÜ odůvodnila podání žaloby u estonských soudů tím, že v Estonsku má centrum svých zájmů dle článku 7 odst. 2 Nařízení Brusel Ibis. U estonských soudů se domáhala, aby primárně nařídily švédskému svazu opravu a odstranění závadných informací, a sekundárně žádala náhradu škody.

Na základě rozhodnutí Soudního dvora ve věci Bolagsupplysningen mezinárodní př́íslušnost estonských z titulu „,centra zájmư “ poškozeného dána není. Vzhledem k tomu, že údajně poškozující informace byly napsány ve švédštině (jazyce, kterému Estonci údajně bez překladu nerozumí) a pokles obratu byl vyčíslen ve švédských korunách, je možné dovodit, že svou hlavní obchodní činnost provozuje ve Švédsku. Tudíž i centrum jejích zájmů se nachází ve Švédsku. Právě v tomto státě bylo poškození pověsti žalobce pocit'ováno nejsilněji. ${ }^{86}$ Skutečnost, že má v Estonsku sídlo, resp., že internetové stránky jsou dostupné i v Estonsku, nemůže automaticky založit př́slušnost estonských soudů $z$ tohoto titulu.

Př́slušnost estonských soudů by byla dána na základě článku 7 odst. 2 Nařízení Brusel Ibis jakožto místa škodlivého následku (resp. místa, kde se škoda projevila, bod 3 v tabulce výše). Př́slušnost estonských soudů by byla omezena pouze k rozhodnutí o škodě, ke které došlo na území Estonska. Pokud by společnost Bolagsupplysningen OÜ trvala na požadavku opravy a odstranění informací a náhrady celé škody, musela by podat žalobu u švédských soudů na základě článku 4 a kritéria bydliště žalovaného (bod 1 v tabulce výše) nebo článku 7 odst. 2 a kritéria místa př́íčinného škodlivého jednání, resp. centra jejích zájmů (body 2 a 4 v tabulce výše).

\section{Kritika rozhodnutí ve věci Bolagsupplysningen}

Soudní dvưr dostal prŕležitost upravit svou předchozí judikaturu a zvýšit právní jistotu a předvídatelnost jurisdikčních pravidel. Soudní dvůr se bohužel odchýlil od stanoviska generálního advokáta Bobka, který vyzval k přezkumu širokých pravidel speciální (alternativní) př́slušnosti dle článku 7 odst. 2 Nařízení Brusel Ibis. Pokud jde o obsah zveřejněný na internetu, nepovažoval generální advokát za účelné a vhodné zachovat mozaikovou úpravu vytvořenou rozhodnutím ve věci Shevill a eDate.

Generální advokát Bobek navrhl zachovat dvojkolejnost „místa škodné události“. A to tak, že poškozená osoba by mohla podat žalobu u soudů místa, ze kterého škodná událost pochází. Toto místo se bude ve většině případů shodovat s místem bydliště

86 Rozhodnutí ve věci Bolagsupplysningen, odst. 42.

Jak dále uvedl Soudní dvůr, ,[...] pokud z dỉkazu [...] nevyplývá, že prevážná cást hospodárské činnosti dotčené právnické osoby je vykonávána v určitém členském státé, a proto nelze určit strédisko zájmu právnické osoby [...] této osobè nemùž být priznáno právo podle čl. 7 odst. 2 nařzeni 1215/2012 k podáni žaloby proti údajnému pưvodci tohoto zásahu do jeji pověsti na základě mista projevi újmy, za účlem úplné nábrady škody“. Rozhodnutí ve věci Bolagsupplysningen, odst. 43. 
žalovaného. Pro škodnou událost má význam místo, kde se nachází osoba, která informace zveřejnila, nikoliv místo, kde byl obsah informace zveřejněn. Fyzické umístění serverů, na kterých je informace uložena, by mělo být irelevantní. ${ }^{87}$ Jako druhé možné sudiště generální advokát navrhl místo, kde došlo ke škodě. V případě pomluvy na internetu by se nicméně nemělo jednat o jakékoliv místo, kde je informace dostupná, ale o místo, kde daná osoba podniká nebo je jinak aktivní, jinými slovy „centrum zájmư“. Tímto by došlo k opuštění „mozaiky“, nebot' místo škodlivého následku by bylo omezeno pouze na jediné sudiště. ${ }^{88}$

Žalobce by měl podle generálního advokáta možnost na základě článku 7 odst. 2 Nařízení Brusel Ibis možnost volby mezi dvěma sudišti: místa protiprávního škodlivého jednání, které se bude ve většině př́padů shodovat s místem bydliště žalovaného - původce škodlivé informace (článek 4); nebo centra zájmů poškozeného, které odpovídá místu, kde ke škodě došlo. Oba soudy by byly př́slušné k rozhodnutí o celé náhradě škody a o všech možnostech nápravy dostupných podle vnitrostátního práva, včetně případného soudního př́kazu. ${ }^{89}$

Soudní dvůr „mozaiku“ zachoval, byt' v modifikované podobě. Žalobce stále může na základě článku 7 odst. 2 podat žalobu na náhradu škody u soudů všech států, ve kterých je či byla poškozující informace dostupná a kde došlo k poškození pověsti. Př́íslušnost těchto soudů je nicméně omezena na projednání náhrady škody ve výši, v jaké k ní došlo na daném území. Soudy v rámci této teritoriálně omezené př́slušnosti nemohou rozhodnout o návrhu na opravu nebo odstranění informací z webových stránek. Mozaika zůstala zachována pro náhradu škody.

Soudní dvưr tím také zachoval nesoulad mezi rozsahem soudní př́íslušnosti a navrhovanou nápravou (předběžné opatření, soudní př́kaz apod.). ${ }^{90}$ Soudy, které jsou př́slušné $\mathrm{k}$ rozhodnutí o teritoriálně omezené náhradě škody, nemohou rozhodnout o opatřeních k opravě nebo odstranění informací na internetu. To je na jedné straně smysluplné řešení. Informace na webové stránce jsou jen jedny a není možné, aby jeden soud vydal prríkaz $\mathrm{k}$,částečné“ opravě nebo odstranění informace podle míry škody, která na jeho území vznikla. Na straně druhé, pokud bychom přijali opačnou interpretaci, mohlo by dojít k situaci, kdy každý soud z 28 členských států by mohl vydat soudní př́kaz k opravě nebo odstranění informací z internetu. Je otázkou, jak by se poté tyto př́kazy koordinovaly. Je nutné uvést, že k podobnému problému by mohlo dojít i podle rozhodnutí Soudního dvora, jen v menším počtu jurisdikcí. ${ }^{91}$

\footnotetext{
87 Stanovisko generálního advokáta Bobka ve věci Bolagsupplysningen, odst. 94.

88 Stanovisko generálního advokáta Bobka ve věci Bolagsupplysningen, odst. 96.

89 Stanovisko generálního advokáta Bobka ve věci Bolagsupplysningen, odst. 97.

90 Stanovisko generálního advokáta Bobka ve věci Bolagsupplysningen, odst. 123.

91 VANLEENHOVE, 2018, op. cit., s. 646.
} 
Pokud by došlo k odmítnutí mozaiky, neexistoval by ani tento nesoulad mezi soudní příslušností a nápravou. Soud členského státu, jenž je př́slušný k rozhodnutí o žalobě na náhradu škody z důvodu mimosmluvní odpovědnosti dle Nařízení Brusel Ibis, by měl být př́slušný $\mathrm{k}$ rozhodnutí o všech druzích nápravných opatření, které ve vnitrostátním právu existují, nikoliv pouze o náhradě škody. ${ }^{92}$

Další dosud nevyjasněnou otázkou je, jakým způsobem se má určit „,centrum zájmů poškozeného“ $v$ prŕpadě právnické osoby, která neprovozuje podnikatelskou činnost. Může se jednat o nejrůznější neziskové organizace apod. Touto věcí se Soudní dvůr nezabýval, nebot' žalující společnost Bolagsupplysningen OÜ provozovala obchodní činnost za účelem dosažení zisku. Možnou interpretaci naznačil ve svém stanovisku generální advokát Bobek. V př́padě právnické osoby založené za účelem dosažení zisku by se mohlo jednat o místo, kde společnost dosahuje nejvyššího obratu. $V$ př́padě neziskových organizací by se mohlo jednat o místo, kde se nachází většina jejich „klientů“. V obou dvou př́padech by se jednalo o místa, kde by právnická osoba nejsilněji cítila poškození její pověsti. ${ }^{93}$ Je pravděpodobné, že tato otázka by mohla být v budoucnu k Soudnímu dvoru předložena. Byt' se kritérium „,centrum zájmů poškozeného“ zdá být relativně nejideálnějším řešením, není bez možných rizik. Poskytuje žalobci forum actoris. To je v rozporu s Nařízení Brusel Ibis, které možnost žalovat u „svého“ sudiště poskytuje slabším smluvním stranám v př́padě sporů vyplývajících ze spotřebitelských, pojistných a individuálních pracovních smluv.

Jak bylo uvedeno výše, u fyzické osoby se bude zpravidla jednat o místo bydliště. V případě právnické osoby se podle Soudního dvora jedná o místo, ve kterém provozuje hlavní podnikatelskou činnost; sídlo může být jednou z indicií. ${ }^{44}$ Jak bylo uvedeno dřive, podle Soudního dvora může mít fyzická nebo právnická osoba jen jedno centrum zájmů. U fyzických i právnických osob může existovat více než jedno centrum zájmů ve vztahu k určité žalobě. ${ }^{95}$

92 Jednotlivé národní právní rády se liší v právní úpravě a př́istupu soudů k možným prostředkům nápravy, typicky soudnímu př́kazu k opravě nebo odstranění informací z internetu. BOGDAN, Michal. Website Accessibility as Basis for Jurisdiction under the Brussels I Regulation. Masaryk University Journal of Law and Technology [online]. 2011, roč. 5, s. 4 [cit. 26. 8. 2018]. Dostupné z: https://journals.muni.cz/mujlt/ article/view/2568/2132. Lutz̨i uvádí př́klad anglických soudů, které se staví spíše odmítavě $\mathrm{k}$ možnosti vydání soudního př́kazu proti informacím publikovaným na internetu, jestliže jejich mezinárodní př́slušnost byla založena pouze na tom, že obsah je dostupný z jejich území. Jako př́klad opačného prístupu, tedy ochoty vydat soudní prííkaz, Lutzi uvádí německé soudy. In: LUTZI, 2017, op. cit., s. 692 a judikatura zde uvedená.

93 Stanovisko generálního advokáta Bobka ve věci Bolagsupplysningen, odst. 104.

94 Sídlo jako jedna z možností pro určení mezinárodní prúslušnosti soudů je zcela v souladu s obecnou př́slušností dle článku 4, resp. článku 63 Nařízení Brusel Ibis. Místo sídla používá i Nařízení Evropského parlamentu a Rady (EU) 2015/848 ze dne 20. května 2015 o insolvenčním rúzení. Stanovisko generálního advokáta Bobka ve věci Bolagsupplysningen, odst. 107.

95 Stanovisko generálního advokáta Bobka ve věci Bolagsupplysningen, odst. 116. 


\section{Závěr}

Rozhodnutí Soudního dvora ve věci Bolagsupplysningen je jistě významným příspěvkem k interpretaci pojmu „místo škodné události“ dle článku 7 odst. 2. Nařízení Brusel Ibis. Stanovisko generálního advokáta dalo planou naději, že by mohlo dojít k zásadnějšî změně a úpravě stávající intepretace pojmu „místo škodné události“ v judikatuře Soudního dvora pro př́pady porušení osobnostních práv a pomluvy na internetu. Je škoda, že Soudní dvưr této možnosti nevyužil.

Opuštění „mozaiky“ vytvořené v rámci článku 7 odst. 2 Nařízení Brusel Ibis pro mimosmluvní závazkové vztahy na internetu by vedlo k omezení počtu možných sudišt', ve kterých by původce poškozující informace mohl být žalován, a tím ke zvýšení právní jistoty a předvídatelnosti pravidel pro určení mezinárodní př́slušnosti soudů. Odmítnutí mozaikového přístupu by znovu potvrdilo účel a smysl speciálních (alternativních) pravidel př́slušnosti v Nařízení Brusel Ibis. ${ }^{96}$

$\mathrm{V}$ úvodní části bylo položeno několik otázek. V souladu s analýzou provedenou v tomto článku na ně byly nalezeny odpovědi. Výklad podaný Soudním dvorem v rozhodnutích eDate a Bolagsupplysningen není zcela v souladu s principy a cíli Nařízení Brusel Ibis a jeho pravidel. Soudní dvůr ve své interpretační činnosti nevzal dostatečně do úvahy povahu a způsob šíření informací na internetu. Teritoriální rozdělení škody a tzv. „mozaika“ neodpovídá požadavku zajištění právní jistoty a předvídatelnosti procesních stran. Dochází k upřednostnění speciálních „alternativních“ pravidel před pravidlem obecným. $\mathrm{Na}$ základě uvedených problémových otázek tento článek ověřil pracovní hypotézu: Mozaikový prìstup dle článku 7 odst. 2 Nařżeni Brusel Ibis je v rozporu se zachováním právni jistoty legitimního očekáváni stran v prīpadě mimosmluvnich závazkových vžtabu vanikajícich na internetu, a tím v rozporu s cili a účlem Narízeni Brusel Ibis.

96 Pravidlo „mozaiky“ je velmi problematické nejen pro spory o náhradu škody vyplývající z pomluvy a porušení osobnostních práv na internetu. Mnohem zásadnější problémy činí u sporů vyplývajících z porušení práva duševního vlastnictví, jmenovitě práva autorského, které také spadají do působnosti článku 7 odst. 2 Nařízení Brusel Ibis. Této problematice se tento článek vzhledem ke svému rozsahu výslovně nevěnuje, nicméně je nutné tento problém zmínit. Ochrana práv k duševnímu vlastnictví je podobně jako mezinárodní právo soukromé založena na principu teritoriality a principu národním. Generální advokáti se ve svých stanoviscích konzistentně vyjadřují kriticky k aplikaci „mozaiky“ na porušení práva duševního vlastnictví. Jak uvedl generální advokát Villalón ve stanovisku ve věci Hejduk v odst. 41, v případě nelokalizované škody v důsledku druhu autorského díla a média použitého k jeho sdělování (internet), není možné použít kritérium místa vzniku škody, ale je nutné využít výlučně príslušnost soudů místa, kde došlo k prŕíčinné události. 